\title{
The Effect of Responsive and Proactive Market Orientation on Product Innovation and Company Performance: A Case Study on MSMEs in the Culinary Field in D.I. Yogyakarta
}

\author{
A'bdul Fatach Ichwan', Siti Nursyamsiah ${ }^{2}$ \\ ${ }^{1,2}$ Universitas Islam Indonesia, Yogyakarta \\ siti.nursyamsiah@uii.ac.id
}

\begin{abstract}
This study aims to determine the effect of Responsive and Proactive Market Orientation on Product Innovation and Company Performance. The population in this study is the Micro, Small, and Medium Enterprise (MSME) in the Culinary Division at D.I. Yogyakarta and use 200 respondents as a sample. By using convenience sampling technique, the researchers have the freedom to choose any culinary MSME found around D.I. Yogyakarta to be the respondent. Hypothesis testing using Structural Equation Model (SEM) analysis. The findings show that there is a positive influence of responsive market orientation on product innovation performance, proactive market orientation on product innovation performance, product innovation performance on the company's market performance, and the company's market performance on the company's financial performance. The findings of this study contribute to MSMEs that information about market orientation adopted by business actors or companies can affect the performance of new product innovations in the market to improve the company's market performance which then affects the company's financial performance.
\end{abstract}

\section{Article Info}

- Received : October 31, 2018

- Revised : November 28, 2018

- Published : January 5, 2019

- No. Pages : $32-42$

- DOI : $10.33019 /$ ijbe.v3i1.117

- JEL : A11, D13, P17

- Keywords : responsive market orientation, proactive market orientation, product innovation, company performance

\section{Introduction}

In Indonesian business sector, the type of business conducted most by people is Micro, Small, and Medium Enterprise (MSMEs). MSMEs play an essential role in the Indonesian economy as it managed to prove its existence in it. We can see that MSMEs covered $99.99 \%$ of overall business players in Indonesia or as many as 59.26 million units in 2015 (Annual Report of Kemen KUKM, 2016). MSMEs has stabilized economy by opening employment opportunities and distributing income. However, its low productivity rate has lowered its value added for economic activities. MSMEs low productivity and add value are affected by market growth volatility in its respective fields. It occurs due to low market understandings and information. Market globalization marked with the increase of interdependence nature and integration of 
global economy (Hill, 2010) has encouraged the development of marketing science in determining corporate strategies to transform from product-oriented or customer-oriented to market-oriented (Day, 1999).

Market orientation is deemed as an essential concept to determine strategies of a company (Harris, 1996). Market-oriented companies are considered having higher market knowledge and better abilities in communicating with customers. This capability may guarantee a company to gain higher profit than the companies having less market orientation (Day, 1994). Therefore, market orientation profoundly influences the success of companies either in big, medium, or small scales. Unfortunately, most researches about market orientation are limited to big-scale business (Zhang and Duan, 2010). Not many researches discuss market orientation aspect in small and medium industry, especially in Indonesia. Whereas, MSMEs plays an essential and strategic role for the Indonesian economy. It can be seen from a large number of industries in every economic sector, its incredible potential to absorb workforce, and relatively significant contribution to GDP. Moreover, MSME is also considered as a business unit which managed to survive in a crisis period where each big business starts to get unstable (The Asia Foundation, 2001).

D.I. Yogyakarta (DIY)'s MSMEs in the culinary field is an appropriate example to see the development and growth of MSMEs in Indonesia since D.I. Yogyakarta has a small area of 3,133.15 square kilometres with around 3,542,078 population (Permendagri Number 39 of 2015). Assistant for Economy and Development of DIY Regional Secretariat, Budi Wibowo, said D.I. Yogyakarta has around 524,395 SMEs dominating economic growth of 98.4\%. In a holiday season, Yogyakarta becomes one of main tourist destinations in Indonesia and the business activities in this business field are quite high. The businesses of accommodation, as well as food and drink providers, become main contributors for accommodation and food-drink provision business field in DIY's PDRB.

According to the background, this research aims to empirically test the influence of market orientation against innovation and financial performances of Yogyakarta's MSMEs in the culinary field.

\section{Literature Reviews}

\section{Market Orientation and Product Innovation Performance}

Narver et al. (2004) stated market orientation consists of two important behavioural sets. The first behavioural set is responsive market orientation leading to "customer-led" in Slater and Narver (1998) and "customer compelled" in Day (1999) in which every company attempts to find, understand, and satisfy the needs expressed by customers (expressed needs). Responsive market orientation focuses on empirical analysis from currently existing knowledge and experience. The second behavioural set is a proactive market orientation in which every company attempts to find, understand, and satisfy customers' latent needs (latent needs).

To provide a more detailed explanation of the difference between these two market orientation types, Narver et al. (2004) divides consumer needs into two forms, namely expressed needs and latent needs. Expressed needs and expressed solutions are defined as "the needs and solutions of a customer of which customer is aware and, therefore, can express." It means customers know 
and are aware of their needs so they can express them. As an example, consumers have expressed needs in the form of "hunger" whose solution is "food." Here, consumers know what they need and the solution of the needs. Different from expressed needs, Narver et al. (2004) define latent needs and latent solutions as "needs and solutions of which the customer is unaware." Here, consumers are not aware of their needs, so they do not know the solution to meet those needs. It shows that the needs are not really like expressed needs, but customers do not realize or have not realized about these needs. Commonly, a business will firstly pay more attention to expressed needs as the needs realized by customers. However, only fulfilling consumers' expressed needs is not sufficient to attract and maintain consumers since competitors can easily detect expressed needs.

This situation leads to price competition to create superior value for consumers. The price competition becomes inevitable when consumers think there is no value difference among the offers provided by producers or, in other words, producers only offer products which can be easily guessed by consumers (Narver et al., 2004). Narver et al. (2004) stated that finding and satisfying consumers' latent needs can be achieved by leading them. Consumer leading implies the existence of proactivity. In this part, proactive market orientation's role is necessary as it not only responds to currently existing needs but also attempts to lead consumers and create solutions for their latent needs. This behaviour distinguishes proactive market orientation and responsive market orientation.

Zhang and Duan (2010) explained in their research that the culture and behaviour of marketoriented companies generate excellent product innovation and innovation performance. Li et al. (2008) explained based on implemented measurement scale; it can be concluded that many of the studies implicitly refer to the dimension of responsive market orientation. Lilien et al. (2002) explained that expressing customers' latent needs, cooperating with main users, and conducting experiments are usually related to innovation. Focusing on future customer needs can also provide information to companies about new markets and technology advance to improve companies' capabilities to integrate development into product innovation.

According to Trott P, (2005; 2008), innovation, in a broad concept, is not only limited to product, but innovation can also take the form of ideas, means, or objects perceived by a person as something new. Innovation is also usually used to refer to the changes perceived as something new by people who experience it. However, in a marketing context and consumer behaviour context, innovation is related to new products or services, referring to the products which indeed have not existed in the market, and 'new' which refers to different things including perfection or improvement of previous products consumers found in the market (Suryani, 2008). Previous research conducted by Narver et al. (2004) also shows that proactive market orientation has a positive relationship with the success of new products. According to the above findings, the following hypotheses are proposed:

H1A: Responsive Market Orientation positively influences Product Innovation Performance. H1B: Proactive Market Orientation positively influences Product Innovation Performance. 


\section{Market Orientation and Corporate Performance}

The research conducted by Bodlaj (2010) explained that several previous types of research confirm a positive relationship between market orientation and various corporate performance measures. More updated literature about market orientation, according to Bodlaj's research (2010), shows that both market orientation forms are needed for long-term business performance (Sheth and Sisodia, 1999). Narver et al. (2004) explained that developing by only implementing responsive market orientation may not be sufficient for companies to attract and maintain customers. Hence, companies have to keep improving their proactive market orientation to create and maintain sustainable competitive strengths. Similar with several other types of research, then the writer stated that market orientation indirectly influences financial performance through market performance (for example, Homburg and Pflesser, 2000; Gabrijan et al., 2005). Therefore, the following hypotheses are proposed:

H2A: Responsive Market Orientation positively influences Corporate Market Performance. H2B: Proactive Market Orientation positively influences Corporate Market Performance.

According to Bodlaj (2010), innovation is one of the main boosters of business performance and is essential for corporate competitiveness. Every company has to develop new products to survive in the long term. The companies failing to develop new products have placed themselves in a significant risk since their existing products are vulnerable against change of needs and desires of customers, new technology, shorter products' life cycle, an increase of domestic and foreign competitions (Kotler, 2003). The research of Slater \& Narver (2004) stated that business performance is measured from profitability than the determined targets. Several empirical findings confirm a positive relationship between new product performance and business performance (for example, Langerak et al., 2004). Companies can improve their business performances by improving their innovation performances and, therefore, they are suggested to raise their level of novelty since it leads to higher innovation performance (Mateja Bodlaj, 2010). According to this finding, the following hypotheses are proposed:

H3: Product Innovation Performance positively influences Corporate Market Performance.

Business performance can broadly be divided into two groups namely financial and non-financial (Rejc, 2002) in Bodlaj (2010). Financial performance measures in business (for example income, sale growth, additional economic value, and cash flow) are measured with a pause. Market performance measures are an essential group related to non-financial acts. In this research, market performance refers to customer satisfaction and customer loyalty while financial performance refers to sale value, sale growth, and gross profit. Cost decrease with relatively similar product quality will enhance corporate profit regarding corporate performance improvement. Previous researches theoretically or empirically show that market performance has positive impacts on financial performance. Therefore, the following hypotheses are proposed:

H4: Corporate Market Performance positively influences Corporate Financial Performance.

To obtain a deep conceptual overview and frameworks over this research, the following research model is compiled: 


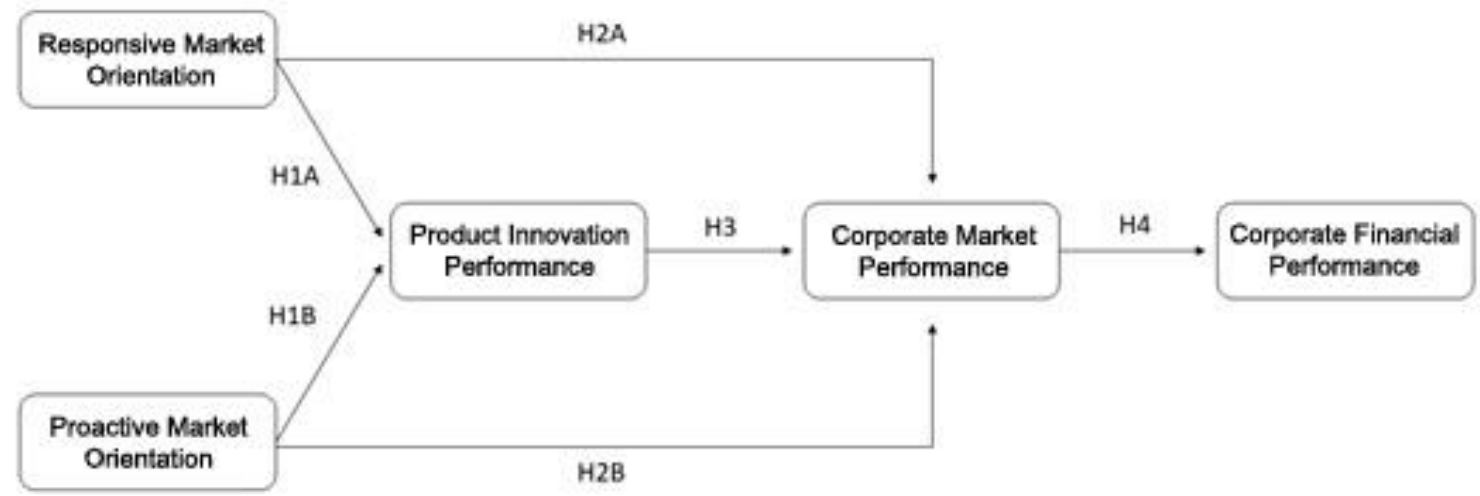

Source: Data processed

Figure 1. Research Model

\section{Research Methods}

\section{Population and Sample}

The population of this research is D.I. Yogyakarta's Micro, Small, and Medium Enterprise (MSMEs) in the culinary field. Samples are collected through Convenience sampling and Purposive sampling methods. Convenience sampling is an unlimited non-probability sampling, in which samples are selected from the members of the population that are easy to find and be interviewed. Purposive sampling is a sample selection method based on certain consideration (Ghozali, 2005). In determining the number of samples, Aderson \& Gerbing (1988) suggested a minimum number of sample for SEM analysis is 100 to 200. Considering the proportion of sample number suggested by the experts, the researcher determined that the minimum samples of this research are 230 respondents to anticipate outlier data. In this research, the samples to be used are 200 UMKMs of the culinary field in Yogyakarta whose characteristics are stated in the following table: From 200 UMKMs as respondents, 98\% have less than 20 employees, $1 \%$ has 20-100 employees, and 1\% has more than 100 employees. According to corporate age, $75 \%$ have less than five years of operation, $22.5 \%$ have 5 to 10 years of operation, and $2.5 \%$ have 11 to 15 years of operation. According to the amount of capital, 57.5\% UMKMs have less than Rp50 million capital, $27 \%$ have Rp50 million to 100 million capital, and $15.5 \%$ have over Rp100 million capital (table 1).

Table 1: Characteristics of Respondents

\begin{tabular}{|c|c|c|}
\hline Characteristics & Frequency & Percentage (\%) \\
\hline According to Number of Employees & 196 & 98 \\
\hline$<20$ Employees & 2 & 1 \\
\hline $20-100$ Employees & 2 & 1 \\
\hline$>100$ Employees & \multicolumn{1}{|}{} \\
\hline According to Corporate Age & 150 & 75 \\
\hline$<5$ years & 45 & 22.5 \\
\hline $5-10$ years &
\end{tabular}




\begin{tabular}{|c|c|c|}
\hline Characteristics & Frequency & Percentage (\%) \\
\hline 11-15 years & 5 & 2.5 \\
\hline According to the Amount of Capital & \multicolumn{2}{|l}{} \\
\hline < Rp50.000.000 & 115 & 57.5 \\
\hline Rp50.000.000- Rp100.000.000 & 54 & 27 \\
\hline$>$ Rp100.000.000 & 31 & 15.5 \\
\hline
\end{tabular}

Source: Compiled Primary Data, 2018

\section{Research Variables}

Research variables are the components which become objects of research or center of attention in research. The variables in this research are as follows: Independent variable of this research is market orientation covering Responsive Market Orientation (X1) and Proactive Market Orientation (X2). Dependent Variable in this research is corporate performance covering Corporate Marketing Performance (Y1), Corporate Financial Performance (Y2), and Product Innovation Performance $(\mathrm{Z})$. The measurements of those variables are adapted from research instruments previously used by Bodlaj (2010).

\section{Results and Discussions}

\section{Descriptive Analysis}

According to Table 2 above, from 200 respondents taken as samples, most respondents stated that all implemented indicators are Good/Agree (Mean of 4.88). It shows that research respondents on average have a proper assessment of responsive and proactive market orientation against product innovation and corporate performance.

Table 2. Respondent Classification for All Variables

\begin{tabular}{|l|c|c|c|}
\hline \multicolumn{1}{|c|}{ Variables } & $\begin{array}{c}\text { Total Mean of } \\
\text { Variables }\end{array}$ & $\begin{array}{c}\text { Mean of } \\
\text { Variables }\end{array}$ & Categories \\
\hline Responsive Market Orientation & 20.02 & 5.01 & Good \\
\hline Proactive Market Orientation & 19.95 & 4.99 & Good \\
\hline Product Innovation Performance & 18.62 & 4.66 & Good \\
\hline Corporate Market Performance & 10.26 & 5.13 & Good \\
\hline Corporate Financial Performance & 9.19 & 4.60 & Good \\
\hline Mean & 15.60 & 4.88 & Good \\
\hline
\end{tabular}

Source: Compiled Primary Data (2018)

\section{Results of Validity and Reliability Tests}

The researcher conducted a validity test for each observed variable or indicator through convergent validity approach. Convergent validity can be seen from the measurement model by determining whether each validly estimated indicator measures the dimension of the concept it tests. An indicator shows significant convergent validity if the variable coefficient of the indicator is higher than the double of its error standard (Anderson and Gerbing, 1988) or has higher critical ratio than the double of its error standard. AMOS Program version 24 also facilitates convergent validity assessment by observing critical value or $t$-value from each indicator. The criteria are that if the indicator's t-value is $\geq 1.96$, it means the indicator is 
significant in the level of $\alpha=0.05$ (Holmes-Smith, 2001). The results of validity and reliability tests to samples are shown in Table 3.

Table 3. Results of Validity and Reliability Tests

\begin{tabular}{|c|c|c|c|c|c|}
\hline Indicators & $\lambda_{i}$ & $\varepsilon_{i}$ & Information & Construct Reliability & Information \\
\hline \multicolumn{6}{|c|}{ Responsive Market Orientation } \\
\hline OPR_1 & 0.631 & 0.023 & Valid & \multirow{4}{*}{0.975} & \multirow{4}{*}{ Reliable } \\
\hline OPR_2 & 0.780 & 0.046 & Valid & & \\
\hline OPR_3 & 0.619 & 0.042 & Valid & & \\
\hline OPR_4 & 0.546 & 0.059 & Valid & & \\
\hline \multicolumn{6}{|c|}{ Proactive Market Orientation } \\
\hline OPP_1 & 0.520 & 0.053 & Valid & \multirow{4}{*}{0.966} & \multirow{4}{*}{ Reliable } \\
\hline OPP_2 & 0.659 & 0.053 & Valid & & \\
\hline OPP_3 & 0.503 & 0.051 & Valid & & \\
\hline OPP_4 & 0.705 & 0.045 & Valid & & \\
\hline \multicolumn{6}{|c|}{ Product Innovation Performance } \\
\hline KIP_1 & 0.712 & 0.052 & Valid & \multirow{4}{*}{0.988} & \multirow{4}{*}{ Reliable } \\
\hline KIP_2 & 0.839 & 0.034 & Valid & & \\
\hline KIP_3 & 0.912 & 0.033 & Valid & & \\
\hline KIP_4 & 0.971 & 0.026 & Valid & & \\
\hline \multicolumn{6}{|c|}{ Corporate Market Performance } \\
\hline KPP_1 & 0.902 & 0.028 & Valid & \multirow{2}{*}{0.984} & \multirow{2}{*}{ Reliable } \\
\hline KPP_2 & 0.882 & 0.024 & Valid & & \\
\hline \multicolumn{6}{|c|}{ Corporate Financial Performance } \\
\hline KKP_1 & 0.816 & 0.038 & Valid & \multirow{2}{*}{0.974} & \multirow{2}{*}{ Reliable } \\
\hline KKP_2 & 0.896 & 0.039 & Valid & & \\
\hline
\end{tabular}

Source: Compiled Primary Data (2018)

The Table 3 shows that statistical probability is $>0.50$ so all questions in questionnaires on question items of Responsive Market Orientation, Proactive Market Orientation, Product Innovation Performance, Corporate Market Performance, and Corporate Financial Performance variables $>$ level of significance $=0.05$ or above 0.1388 of the table are valid. The coefficient of construct reliability is $>0.60$ so all questions in questionnaires on question items of Responsive Market Orientation, Proactive Market Orientation, Product Innovation Performance, Corporate Market Performance, and Corporate Financial Performance variables are reliable.

\section{The result of Model Test}

The analysis tool used in this research is the Structural Equation Model (SEM). This analysis tool is used to whether Responsive Market Orientation will have positive effects to Product Innovation Performance, Proactive Market Orientation will have positive effects on Product Innovation Performance, Responsive Market Orientation will have positive effects on Corporate Market Performance, Product Innovation Performance will have positive effects in Corporate Market Performance, and Corporate Market Performance will have positive effects on Corporate Financial Performance. 
Table 4. The result of Goodness of Fit Model

\begin{tabular}{|c|c|c|c|}
\hline Reference Index Criteria & Reference Value & Test Result & Information \\
\hline Chi-Square $\left(X^{2}\right)$ & Probability $(\mathrm{P})>0.05$ & 122.167 & Good Fit \\
\hline CMIN/df & $\leq 2.00$ & 1.222 & Good Fit \\
\hline $\begin{array}{l}\text { Root mean square error of approximation } \\
\text { (RMSEA) }\end{array}$ & $<0.08$ & 0.033 & Good Fit \\
\hline The goodness of Fit Index (GFI) & $\geq 0.90$ & 0.928 & Good Fit \\
\hline Adjusted Goodness of Fit Index (AGFI) & $\geq 0.90$ & 0.902 & Good Fit \\
\hline Comparative fit index (CFI) & $>0.9$ (approaching 1) & 0.980 & Good Fit \\
\hline Parsimonious comparative fit index (PCFI) & $>0.6$ & 0.817 & Good Fit \\
\hline Akaike information criteria (AIC) & $\begin{array}{c}\text { AIC }<\text { AIC saturated } \\
\text { model \& independence } \\
\text { mode }\end{array}$ & 194.893 & Good Fit \\
\hline
\end{tabular}

Source: Compiled Primary Data. Structural Equation Modeling (SEM), 2018

The following is the result of the goodness of fit index test and its cut-off values used in this research which will later be used to test whether a model can be accepted or rejected. According to Table 4, all test results have met required reference value. Therefore, it can be concluded that structural equation model in this research is fit (having compatibility).

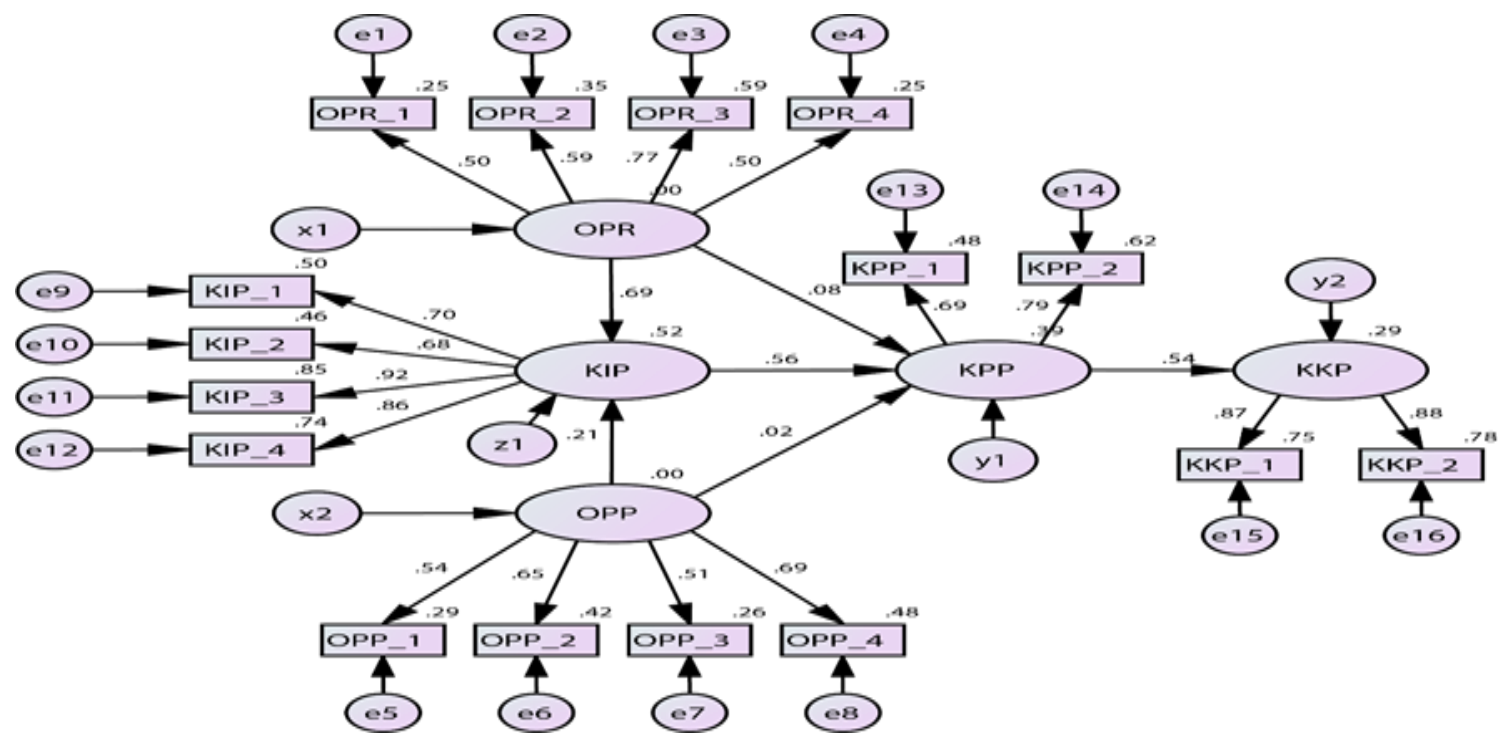

Source: Output, data processed

Figure 2. Structural Equation Model

\section{The result of Hypothesis Test}

The calculation using a statistical computer program, AMOS 24, shows that probability values among the influences of Responsive Market Orientation to Product Innovation Performance, Proactive Market Orientation to Product Innovation Performance, Product Innovation Performance to Corporate Market Performance, and Corporate Market Performance to Corporate Financial Performance is $<$ Level of Significance $=0.05$. Meanwhile, the probability values between the influences of Responsive Market Orientation to Corporate Market Performance and 
Proactive Market Orientation to Corporate Market Performance are $>$ Level of Significance $=$ 0.05. This research concludes that there are influences among Responsive Market Orientation to Product Innovation performance, Proactive Market Orientation to Product Innovation Performance, Product Innovation Performance to Corporate Market Performance, and Corporate Market Performance to Corporate Financial Performance. However, this research also concludes that there are no influences among Responsive Market Orientation to Corporate Market Performance and Proactive Market Orientation to Corporate Market Performance. These results indicate a mediation role of innovation performance connecting responsive market orientation and proactive market orientation with corporate market performance as shown in Table 5 below.

Table 5. Result of Estimated Structural Equation Model (SEM)

\begin{tabular}{|c|c|c|c|c|c|c|}
\hline Hypotheses & $\begin{array}{c}\text { Regression } \\
\text { Route }\end{array}$ & $\begin{array}{c}\text { Coefficient of } \\
\text { Regression }\end{array}$ & $\begin{array}{c}\text { Error } \\
\text { Standard }\end{array}$ & $\begin{array}{c}\text { t- } \\
\text { calculation }\end{array}$ & Prob. & Information \\
\hline H1A & OPR-KIP & 2.066 & 0.368 & 5.606 & 0.000 & Significant \\
\hline H1B & OPP-KIP & 0.382 & 0.135 & 2.828 & 0.005 & Significant \\
\hline H2A & OPR-KPP & 0.148 & 0.242 & 0.610 & 0.542 & Not Significant \\
\hline H2B & OPP-KPP & 0.022 & 0.095 & 0.230 & 0.818 & Not Significant \\
\hline H3 & KIP-KPP & 0.331 & 0.078 & 4.227 & 0.000 & Significant \\
\hline H4 & KPP-KKP & 0.830 & 0.128 & 6.478 & 0.000 & Significant \\
\hline
\end{tabular}

Source: Compiled Primary Data. Structural Equation Modeling (SEM), 2018

\section{Conclusion and Suggestion}

From six hypotheses regarding the influences of responsive and proactive market orientations to product innovation performance and corporate performance covering market and financial performance, responsive and proactive market orientations have influences over product innovation performance. Therefore, it takes consistency to adopt one of the market orientations since both of them influence innovation performance in producing new products to succeed in markets. Meanwhile, the hypotheses testing the influences of responsive market orientation and proactive market orientation to market performance are not proven. The hypotheses testing the influence of product innovation performance to market performance and influence of market performance to financial performance are proven as significant.

Our study provides several guidelines for managers involved in new product development. First, research finding shows that market orientation is an important determinant of new product performance and it even has a more prominent role in product innovation than market orientation since market orientation highlights customer focus and competitor leading companies to explore products' market trends better. To generate greater customer profit, business with higher market orientation level tends to have competent capabilities to improve product innovation performance. Therefore, in the case of strategic resource shortage, producers have to prioritize the implementation of market orientation strategies. Second, our research determines the importance of both market orientation types for producers during the product innovation process. The implication is that management can influence the efficiency and effectiveness of new 
product development by investing in organizational programs which improve companies' market-oriented culture.

Appropriate behaviour for MSMEs adopting responsive market orientation is to always focus on empirical analyses from knowledge and experience to meet currently existing customer needs (expressed needs). According to feedback from customers, companies can improve products by focusing on product improvement areas as customers suggested. Meanwhile, appropriate behaviour for proactive market orientation is that each company keeps attempting to find, understand, and satisfy customers' latent needs (latent needs) and focusing on innovation at all organizational levels. Therefore, a business player or company must be able to synchronize owned resources to be used to create effective and efficient strategies in creating good product innovations.

Market performance improvement can be achieved by using and creating new products which meet the desires and needs of target people. It is essential to maintain existing customer to establish loyalty to the products by maintaining or improving its qualities. Therefore, corporate financial performance can be achieved if product innovation performance influencing corporate market performance can be improved.

\section{Acknowledgement}

The authors are thankful to Universitas Islam Indonesia, Yogyakarta, for supporting this research and providing the necessary facilities.

\section{References}

1) Anderson, J., \& Gerbing, D, (1988). Structural Equation Modeling in Practice: A Review and Recommended Two-Step Approach. Psychological Bulletin Vol. 103, No. 3, 411-423.

2) Badan Pusat Statistik Balai Statistik Daerah BAPPEDA DIY. (2017). Laporan Akhir Analisis Produk Domestik Regional Bruto Daerah Istimewa Yogyakarta 2012-2016. D.I. Yogyakarta.

3) Bodlaj, M. (2010). The Impact of a Responsive and Proactive Market Orientation on Innovation and Business Performance. Economic and Business Review, Vol. 12, 241-261.

4) Day, G. (1994). The Capabilities of Market-Driven Organizations, Journal of Marketing, Vol. 58, 3752.

5) Day, G. (1999). Misconceptions about Market Orientation, Journal of Market-Focused Management Vol. 4, No. 1, 5-16.

6) Foundation, T. A. (2001), Annual Report: Working to Build a Peaceful, Prosperous, and Open AsiaPacific Community.

7) Gabrijan, V. (2005), The impact of marketing resources on organizational performance. Naše gospodarstvo, 92-103.

8) Ghozali, I. (2005), Aplikasi Analisis Multivariate dengan SPSS. Semarang: Badan Penerbit Universitas Diponegoro Semarang.

9) Harris, L. (1996). Benchmarking Against The Theory of Market Orientation. Management Decision, Vol. 34, No. 2, 25-29.

10) Hill, C. W. (2010). International Business: Competing in The Global Marketplace, 9th Edition. New York: McGraw-Hill. 
11) Holmes-Smith, P. (2001). Introduction to Structural Equation Modelling Using LISREL. ACSPRIWinter Training Program, Perth.

12) Homburg, C., \& Pflesser, C. (2000). A Multiple-Layer Model of Market-Oriented Organizational Culture: Measurement Issues and Performance Outcomes. Journal of Marketing Research ,Vol. 37, No, 4, 449-462.

13) Kementrian Koperasi dan Usaha Kecil dan Menengah Republik Indonesia. (2016). Laporan Tahunan Kementrian Koperasi dan Usaha Kecil dan Menengah. D.I. Yogyakarta.

14) Kode dan Data Wilayah Administrasi Pemerintahan. (2018, January 11). Diambil kembali dari Kementrian Dalam Negeri : http://www.kemendagri.go.id/produk-hukum/2015/03/16/dfg

15) Kotler, P. (2003). Marketing Management, 11th Edition. New Jersey: Prentice Hall Inc.

16) Langerak, F., Hultink, E. J., \& Robben, H. S. (2004). The Impact of Market Orientation, Product Advantage, and Launch Proficiency on New Product Performance and Organizational Performance. Journal of Product Innovation Management, Vol. 21, No. 2, 79-94.

17) Li, T., Tsalikis, J., \& Seaton, B. (2008). The International Business Ethics Index: Asian Emerging Economies. Journal of Business Ethics, Vol. 80, No. 4, 643-651.

18) Lilien, G., Morrison, P., Searls, K., Sonnack, M., \& Hippel, E. (2002). Performance Assessment of the Lead User Idea-Generation Process for New Product Development. Management Science, Vol. 48, No. 4, 1042-1059.

19) Narver, J., Slater, S., \& MacLachlan, D. (2004). Responsive and Proactive Market Orientation and New Product Success. Journal of Product Innovation Management, Vol. 21, No. 5, 334-347.

20) Rejc, A. (2002). Role and Significance of Non-financial Information in Light of Firm Performance, Theory and Empirical Investigation, PhD Dissertation, Faculty of Economics, Ljubljana.

21) Sheth, J., \& Sisodia, R. (1999). Revisiting Marketing's Lawlike Generalizations. Journal of the Academy of Marketing Science, Vol. 27, No.1, 71-87.

22) Suryani, T. (2008). Perilaku Konsumen; Implikasi Pada Strategi Pemasaran. Yogyakarta: Graha Ilmu.

23) Trott, P. (2005). Innovation Management and New Product Development, 3th Edition. Harlow: Pearson Education.

24) Trott, P. (2008). Innovation Management and New Product Development, 4th Edition. Harlow: Pearson Education.

25) Zhang, J., \& Duan, Y. (2010). The Impact of Different Types of Market Orientation on Product Innovation Performance. Journal of Management Decision, Vol. 48, No. 6, 849-867.

26) Zhang, J., \& Duan, Y. (2010). The Impact of Different Types of Market Orientation On Product Innovation Performance: Evidence from Chinese Manufacturers. Journal of Management Decision ,Vol. 48, No. 8, 849-867. 